\title{
Substituted benzoic acid benzylidene/furan-2-yl-methylene hydrazides: synthesis, antimicrobial evaluation and QSAR analysis
}

\author{
Pradeep Kumar, Balasubramanian Narasimhan,* and Deepika Sharma \\ Department of Pharmaceutical Sciences, Guru Jambheshwar University of science and \\ Technology, Hisar-125001, India \\ E-mail:naru2000us@yahoo.com
}

\begin{abstract}
Development of new antimicrobial agents is increasingly important due to the resistance of microbes to the known antimicrobial drugs. In the present work substituted benzoic acid hydrazides (1-10) were condensed with substituted aromatic and heteroaromatic aldehydes to yield the target products (11-20). The synthesized compounds were tested in vitro for their antimicrobial activity against Gram positive, Gram negative bacterial and fungal species. The QSAR analysis applied to determine the correlation of antimicrobial activity of substituted hydrazide derivatives with their physicochemical properties indicated the importance of electronic parameters, dipole moment $(\mu)$ and energy of lowest unoccupied molecular orbital (LUMO) in describing antibacterial and antifungal activity respectively.
\end{abstract}

Keywords: Antimicrobial agents, chemical synthesis, QSAR, LOO method

\section{Introduction}

Disease causing microbes that have become resistant to drug therapy are an increasing public health problem nowadays. ${ }^{1}$ There is a real need for discovery of new compounds endowed with antimicrobial activity, possibly acting through mechanisms of actions, which are distinct from those of well known classes of antimicrobial agents to which many clinically relevant pathogens are now resistant. ${ }^{2}$

Hydrazide analogues also possess other biological activities like anticonvulsant, ${ }^{3}$ antidepressant, ${ }^{4}$ anti-inflammatory, ${ }^{5}$ antimalarial, ${ }^{6}$ antimycobacterial, ${ }^{7}$ anticancer ${ }^{8}$ and antimicrobial ${ }^{9-12}$ activities. QSAR is one of the oldest and most widely used methods in computational drug design. It employs statistical methods (typically regression) to derive quantitative relationships linking chemical structure and biological activity. ${ }^{13}$

In view of the above discussion and as a part of our ongoing project devoted to the synthesis and QSAR studies of biologically active molecules, ${ }^{14-26}$ in the present study we report the 
synthesis, antimicrobial evaluation and QSAR studies of substituted benzoic acid benzylidene/furan-2-yl-methylene hydrazides.

\section{Results and Discussion}

The reaction between substituted benzoic acid and thionyl chloride yielded corresponding acid chlorides, which on reaction with hydrazine afforded the corresponding hydrazides (1-10) in appreciable yield. Further the hydrazides were condensed with substituted aldehydes to yield the substituted benzoic acid benzylidene/furan-2-yl-methylene hydrazides (11-20) (Scheme 1). The physicochemical data of synthesized compounds are presented in Table 1.

The structures of compounds 1-20 were assigned by IR and ${ }^{1} \mathrm{H}-\mathrm{NMR}$ spectroscopic data, which are consistent with the proposed molecular structures. Presence of two aromatic rings in structure of compound 19 was confirmed by strong out of plane deformation $(\mathrm{C}-\mathrm{H})$ bending at $795.58 \mathrm{~cm}^{-1}$ in its IR spectra. Moreover, presence of aryl primary amine group in compound 19 was indicated by appearance of strong bands at $1280.65 \mathrm{~cm}^{-1}(\mathrm{C}-\mathrm{N}$ stretching of aryl primary amine) in IR spectra. The presence of the $\mathrm{Cl}$ atom in compound $\mathbf{6}$ and $\mathrm{NO}_{2}$ group in compound $\mathbf{3}$ were indicated by the appearance of peaks at $731.94 \mathrm{~cm}^{-1}$ and $1524.62 \mathrm{~cm}^{-1}$ respectively.

${ }^{1} \mathrm{H}-\mathrm{NMR}$ spectral study gave the multiplet signal between $6.5-8.5 \delta \mathrm{ppm}$, which is indicative of aromatic proton. The compound 5 showed singlet at $\delta 2.33 \mathrm{ppm}$ due to the $\mathrm{CH}_{3}$ group (Ar $\mathrm{CH}_{3}$ ), and a multiplet at $\delta 7.16-7.83 \mathrm{ppm}$ was observed for aromatic protons. The presence of multiplets at $\delta 6.50-6.52 \mathrm{ppm}$ and $6.70-7.78 \mathrm{ppm}$ indicated the presence of aromatic protons of furan $(3 \mathrm{H})$ and benzene $(4 \mathrm{H})$ ring of compound 19. Further the presence of the $\mathrm{N}=\mathrm{CH}$ fragment in compound 19 was indicated by appearance of a signal at $\delta 7.36 \mathrm{ppm}$.

Twenty compounds were screened in vitro for their antimicrobial activities against two Gram positive bacteria - Staphylococcus aureus, Bacillus subtilis; Gram negative bacterium Escherichia coli and a fungal strain - Aspergillus niger by two fold tube dilution method ${ }^{27}$ and their antimicrobial activity was compared with ciprofloxacin and fluconazole as control drugs for antibacterial and antifungal activity respectively. The results of antimicrobial evaluation are presented in Table 2. The compounds showed better antibacterial activity than their antifungal activity. The deduced patterns of antimicrobial activity of substituted hydrazides are in the following order.

B. subtilis $>$ E. coli $>$ S. aureus $>$ A. niger.

The compounds $\mathbf{6}$ and $\mathbf{1 6}$ are the most effective compounds against $S$. aureus with pMICsa value of 1.60 and 1.67 respectively. Against B. subtilis the compounds 11, 12, 16 and 19 showed the better activity in comparison to other compounds synthesized. The antimicrobial spectrum of substituted hydrazides against $E$. coli demonstrated that compounds 11, 12 and $\mathbf{1 6}$ were the most active ones with pMICec value of 1.97, 2.03 and 1.80 respectively. From the above discussion it 
is evident that compounds 11, 12 and 16 emerged as most active antibacterial substituted hydrazides. The compounds exhibited very weak activity against $A$. niger with a maximum pMICan value of $1.54,1.54$ and 1.52 with compounds 7,10 and 13 respectively.

From the analysis of structures and the activity displayed, some structure-activity relationships can be extracted. (a) The structural requirements for antibacterial and antifungal activity are different for substituted hydrazides. This is evidenced by the fact that the most active antibacterial compounds 11, 12 and 16 shown least antifungal activity and compounds 7, 10 and 13 being the most active antifungal compounds have shown least antibacterial activity. The different structural requirements for activity against different microorganisms are similar to the results observed by M. Sortino et al. ${ }^{28}$ (b) The presence of electron-withdrawing groups (-NO $\mathrm{NO}_{2}$, $\mathrm{Cl},-\mathrm{Br}$ ) on aromatic ring improved the antimicrobial activity of compounds $7,10,11,12,13$ and 16. 

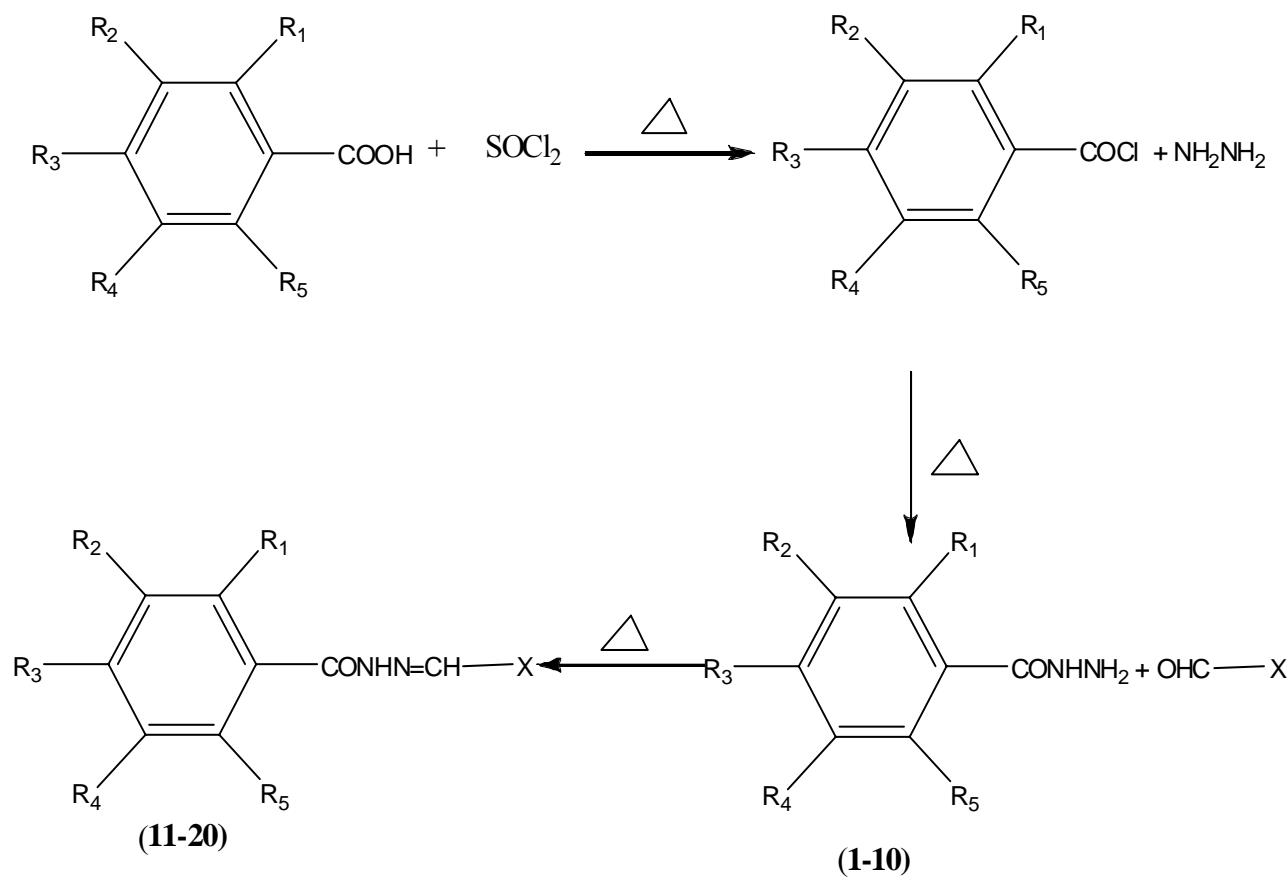

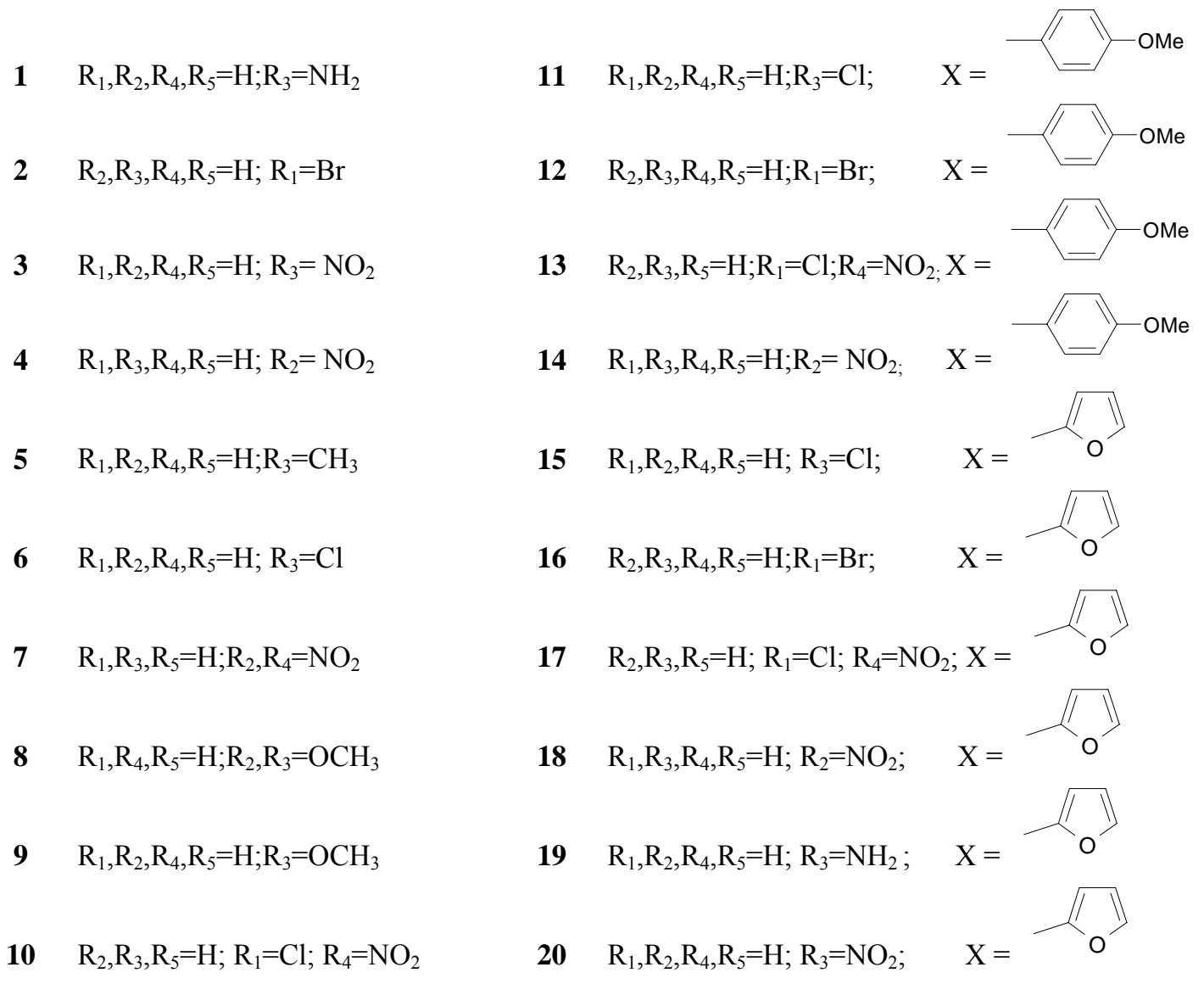

Scheme 1. Syntheses of substituted benzoic acid benzylidene/furan-2-yl-methylene hydrazides. 
Table 1. Physicochemical characteristics of substituted benzoic acid benzylidene/furan-2-ylmethylene hydrazides

\begin{tabular}{clcccc}
\hline Comp. & Mol. Formula & M. Wt. & m.p. & Rf Value & \% Yield \\
\hline $\mathbf{1}$ & $\mathrm{C}_{7} \mathrm{H}_{9} \mathrm{~N}_{3} \mathrm{O}$ & 151 & $130-133$ & $0.31^{\mathrm{a}}$ & 54.7 \\
$\mathbf{2}$ & $\mathrm{C}_{7} \mathrm{H}_{7} \mathrm{~N}_{2} \mathrm{OBr}$ & 216 & $55-58$ & $0.44^{\mathrm{f}}$ & 66.0 \\
$\mathbf{3}$ & $\mathrm{C}_{7} \mathrm{H}_{7} \mathrm{~N}_{3} \mathrm{O}_{3}$ & 181 & $90-93$ & $0.12^{\mathrm{c}}$ & 79.9 \\
$\mathbf{4}$ & $\mathrm{C}_{7} \mathrm{H}_{7} \mathrm{~N}_{3} \mathrm{O}_{3}$ & 181 & $105-108$ & $0.72^{\mathrm{d}}$ & 83.0 \\
$\mathbf{5}$ & $\mathrm{C}_{8} \mathrm{H}_{10} \mathrm{~N}_{2} \mathrm{O}$ & 150 & $35-38$ & $0.58^{\mathrm{a}}$ & 63.0 \\
$\mathbf{6}$ & $\mathrm{C}_{7} \mathrm{H}_{7} \mathrm{~N}_{2} \mathrm{ClO}$ & 171 & $145-148$ & $0.80^{\mathrm{b}}$ & 46.0 \\
$\mathbf{7}$ & $\mathrm{C}_{7} \mathrm{H}_{6} \mathrm{~N}_{4} \mathrm{O}_{5}$ & 226 & $35-38$ & $0.20^{\mathrm{b}}$ & 73.5 \\
$\mathbf{8}$ & $\mathrm{C}_{9} \mathrm{H}_{12} \mathrm{~N}_{2} \mathrm{O}_{3}$ & 196 & $60-63$ & $0.30^{\mathrm{c}}$ & 54.0 \\
$\mathbf{9}$ & $\mathrm{C}_{8} \mathrm{H}_{10} \mathrm{~N}_{2} \mathrm{O}_{2}$ & 166 & $45-48$ & $0.63^{\mathrm{e}}$ & 73.4 \\
$\mathbf{1 0}$ & $\mathrm{C}_{7} \mathrm{H}_{6} \mathrm{~N}_{3} \mathrm{O}_{3} \mathrm{Cl}$ & 201 & $40-43$ & $0.35^{\mathrm{a}}$ & 74.0 \\
$\mathbf{1 1}$ & $\mathrm{C}_{15} \mathrm{H}_{13} \mathrm{~N}_{2} \mathrm{O}_{2} \mathrm{Cl}$ & 289 & $180-183$ & $0.84^{\mathrm{g}}$ & 60.0 \\
$\mathbf{1 2}$ & $\mathrm{C}_{15} \mathrm{H}_{13} \mathrm{~N}_{2} \mathrm{O}_{2} \mathrm{Br}$ & 333 & $210-213$ & $0.55^{\mathrm{g}}$ & 45.6 \\
$\mathbf{1 3}$ & $\mathrm{C}_{15} \mathrm{H}_{12} \mathrm{~N}_{3} \mathrm{O}_{4} \mathrm{Cl}$ & 334 & $130-133$ & $0.90^{\mathrm{g}}$ & 51.3 \\
$\mathbf{1 4}$ & $\mathrm{C}_{15} \mathrm{H}_{13} \mathrm{~N}_{3} \mathrm{O}_{4}$ & 299 & $70-73$ & $0.90^{\mathrm{g}}$ & 33.4 \\
$\mathbf{1 5}$ & $\mathrm{C}_{12} \mathrm{H}_{9} \mathrm{~N}_{2} \mathrm{O}_{2} \mathrm{Cl}$ & 251 & $205-208$ & $0.54^{\mathrm{g}}$ & 62.0 \\
$\mathbf{1 6}$ & $\mathrm{C}_{12} \mathrm{H}_{9} \mathrm{~N}_{2} \mathrm{O}_{2} \mathrm{Br}$ & 293 & $240-243$ & $0.65^{\mathrm{g}}$ & 21.7 \\
$\mathbf{1 7}$ & $\mathrm{C}_{12} \mathrm{H}_{8} \mathrm{~N}_{3} \mathrm{O}_{4} \mathrm{Cl}$ & 296 & $140-143$ & $0.47^{\mathrm{g}}$ & 28.2 \\
$\mathbf{1 8}$ & $\mathrm{C}_{12} \mathrm{H}_{9} \mathrm{~N}_{3} \mathrm{O}_{4}$ & 261 & $90-93$ & $0.72^{\mathrm{g}}$ & 55.6 \\
$\mathbf{1 9}$ & $\mathrm{C}_{12} \mathrm{H}_{11} \mathrm{~N}_{3} \mathrm{O}_{2}$ & 231 & $100-103$ & $0.50^{\mathrm{g}}$ & 61.5 \\
$\mathbf{2 0}$ & $\mathrm{C}_{12} \mathrm{H}_{9} \mathrm{~N}_{3} \mathrm{O}_{4}$ & 261 & $190-193$ & $0.34^{\mathrm{g}}$ & 25.0 \\
\hline
\end{tabular}

${ }^{\mathrm{a}}$ Benzene; ${ }^{\mathrm{b}}$ Chloroform:Benzene:Glacial Acetic Acid(9:3:3); ${ }^{\mathrm{c}}$ Toluene: Chloroform(7:3); ${ }^{\mathrm{e}}$ Hexane:Ethyl Acetate(9:1) ; ${ }^{\mathrm{d}}$ Hexane:Ethyl Acetate(4:1) ; ${ }^{\mathrm{f}}$ Hexane:Ethyl Acetate(7:1); ${ }^{g}$ Chloroform:Acetone $(9: 1)$

The role of electron withdrawing group in improving antimicrobial activities is supported by the studies of Sharma et $a .^{29}$ (c) From the analysis of structures of most active antibacterial compounds 11, 12 and 16 it may be concluded that among the electron-withdrawing groups ($\mathrm{NO}_{2},-\mathrm{Cl},-\mathrm{Br}$ ), the halo groups on the aromatic ring are necessary for the antibacterial activity. Further it may be possible that the introduction of electron-withdrawing halo group on the second aromatic ring may further improve the antibacterial activity of these compounds. (d) The introduction of an additional electron-withdrawing halo group (-Cl) to the compounds $\mathbf{1 0}$ and $\mathbf{1 3}$ did not appreciably improve antimicrobial activity in comparison to compound $\mathbf{7}$ which contains $\mathrm{NO}_{2}$ group as an electron-withdrawing moiety as in case of compounds $\mathbf{1 0}$ and $\mathbf{1 3}$. This indicated that the introduction of $\mathrm{NO}_{2}$ group may improve antifungal activity. (e) From the points (c) and (d), it may be concluded that the introduction of $\mathrm{NO}_{2}$ group as an electron-withdrawing moiety to aromatic ring may improve antifungal activity, whereas introduction of halo group to aromatic 
ring as an electron-withdrawing moiety may improve antibacterial activity. This further supports the fact that different structural requirements are necessary for antibacterial and antifungal activity of substituted hydrazides. The SAR analyses of substituted hydrazides are summarized in Figure 1.

Table 2. Antimicrobial activity of substituted benzoic acid benzylidene/furan-2-yl-methylene hydrazides

\begin{tabular}{ccccc}
\hline Comp & pMICsa & pMICbs & pMICec & pMICan \\
\hline $\mathbf{1}$ & 1.40 & 1.38 & 1.38 & 1.38 \\
$\mathbf{2}$ & 1.54 & 1.54 & 1.54 & 1.41 \\
$\mathbf{3}$ & 1.46 & 1.46 & 1.46 & 1.46 \\
$\mathbf{4}$ & 1.46 & 1.46 & 1.46 & 1.46 \\
$\mathbf{5}$ & 1.38 & 1.38 & 1.38 & 1.38 \\
$\mathbf{6}$ & 1.60 & 1.44 & 1.44 & 1.44 \\
$\mathbf{7}$ & 1.26 & 1.56 & 1.26 & 1.54 \\
$\mathbf{8}$ & 1.50 & 2.06 & 1.50 & 1.36 \\
$\mathbf{9}$ & 1.42 & 1.12 & 1.40 & 1.42 \\
$\mathbf{1 0}$ & 1.48 & 1.84 & 1.24 & 1.54 \\
$\mathbf{1 1}$ & 1.50 & 2.57 & 1.97 & 1.36 \\
$\mathbf{1 2}$ & 1.57 & 2.63 & 2.03 & 1.43 \\
$\mathbf{1 3}$ & 0.82 & 0.82 & 0.82 & 1.52 \\
$\mathbf{1 4}$ & 0.78 & 0.70 & 0.70 & 1.45 \\
$\mathbf{1 5}$ & 1.60 & 2.50 & 1.60 & 1.40 \\
$\mathbf{1 6}$ & 1.67 & 2.57 & 1.80 & 1.37 \\
$\mathbf{1 7}$ & 1.50 & 2.20 & 1.50 & 1.46 \\
$\mathbf{1 8}$ & 1.26 & 1.26 & 1.26 & 1.43 \\
$\mathbf{1 9}$ & 1.50 & 2.47 & 1.60 & 1.36 \\
$\mathbf{2 0}$ & 1.50 & 1.90 & 1.62 & 1.51 \\
$\mathbf{S D}$ & 0.23 & 0.60 & 0.32 & 0.06 \\
Std. Drug & $3.33^{\mathrm{a}}$ & $3.33^{\mathrm{a}}$ & $3.33^{\mathrm{a}}$ & $2.64^{\mathrm{b}}$ \\
\hline $\mathbf{5 t a}$ & & 5 & &
\end{tabular}

* SD- Standard deviation; ${ }^{\mathrm{a} C i p r o f l o x a c i n ;}{ }^{\mathrm{b}}$ Fluconazole 


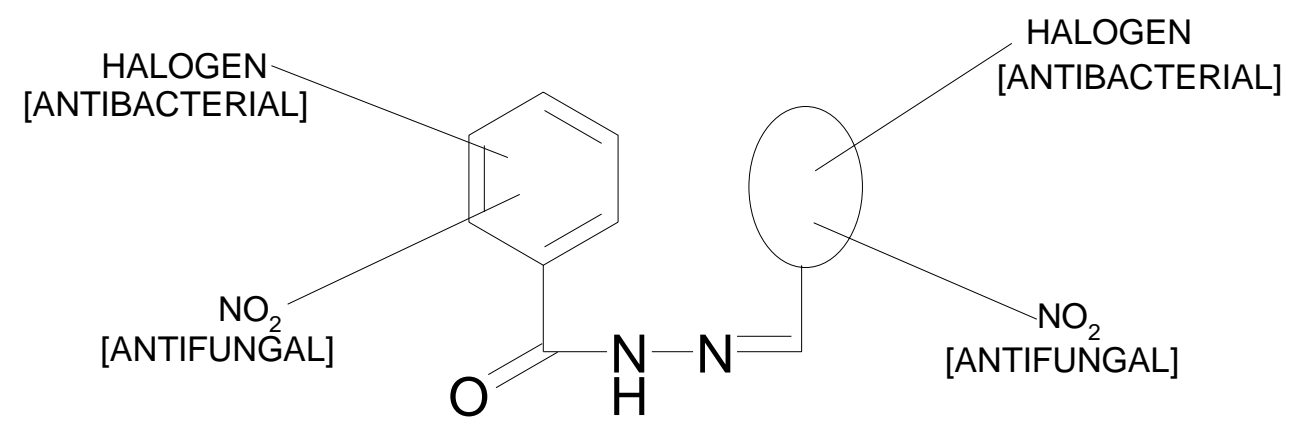

$\rightarrow$ May be aromatic or heteroaromatic

Figure 1. Structural requirement for the antimicrobial activity of substituted benzoic acid benzylidene/furan-2-yl-methylene hydrazides.

In order to identify substituent effect on antimicrobial activity, quantitative structure-activity relationship (QSAR) studies of title compounds were performed. Biological activity data (MIC) were calibrated to their logarithmic values (pMIC) in micromoles and are listed in Table 2. The compounds were analyzed by physicochemical-based QSAR (Hansch) approach using different physicochemical parameters $^{30-36}$ (Table 3) as independent and pMIC values as dependent variables. These QSAR descriptors of substituted hydrazides were calculated using the molecular package TSAR 3.3 for Windows ${ }^{37}$ and the value of selected descriptors used in the regression analysis are presented in Table 4.

A correlation analysis was performed on all the descriptors, depending on the intercorrelation among the independent descriptors and also their individual correlation with antimicrobial activity. The correlation matrix elicited in Table 5, indicates the correlation of antibacterial activity of substituted hydrazides with $S$. aureus. The correlation matrix depicted in Table 5 indicated that there is a high autocorrelation $(\mathrm{r}>0.7)$ observed between the molecular descriptors except with dipole moment $(\mu)$ and energy of lowest unoccupied molecular orbital (LUMO). The high and low autocorrelation was observed between $\kappa_{1}$ and $\kappa \alpha_{1}(\mathrm{r}=0.996)$ and $\log \mathrm{P}$ and LUMO $(\mathrm{r}=0.017)$ respectively. 
Table 3. QSAR descriptors used in the study

\begin{tabular}{clc}
\hline S.No. & QSAR descriptor & Type \\
\hline 1 & Log P & Lipophilic \\
2 & Zero order molecular connectivity index $\left({ }^{0} \chi\right)$ & Topological \\
3 & First order molecular connectivity index $\left(\left(^{1} \chi\right)\right.$ & Topological \\
4 & Second order molecular connectivity index $\left({ }^{2} \chi\right)$ & Topological \\
5 & Valence zero order molecular connectivity index $\left({ }^{0} \chi^{\mathrm{v}}\right)$ & Topological \\
6 & Valence first order molecular connectivity index $\left({ }^{1} \chi^{\mathrm{v}}\right)$ & Topological \\
7 & Valence second order molecular connectivity index $\left({ }^{2} \chi^{\mathrm{v}}\right)$ & Topological \\
8 & Kier's alpha first order shape index $\left(\kappa \alpha_{1}\right)$ & Topological \\
9 & Kier's alpha second order shape index $\left(\kappa \alpha_{2}\right)$ & Topological \\
10 & Kier's first order shape index $\left(\kappa_{1}\right)$ & Topological \\
11 & Randic topological index & Topological \\
12 & Balaban topological index & Topological \\
13 & Wiener's topological index & Topological \\
14 & Kier's second order shape index $\left(\kappa_{2}\right)$ & Topological \\
15 & Ionization potential & Electronic \\
16 & Dipole moment $(\mu)$ & Electronic \\
17 & Energy of highest occupied molecular orbital $(\mathrm{HOMO})$ & Electronic \\
18 & Energy of lowest unoccupied molecular orbital (LUMO) & Electronic \\
19 & Total energy (Te) & Electronic \\
20 & Molar refractivity (MR) & Steric \\
21 & Solvent accessible surface area (SASA) & Geometrical \\
\hline
\end{tabular}

The antibacterial activity of substituted hydrazides against $S$. aureus is best described using the molecular descriptor, dipole moment $(r=-0.916$, Eq. 1).

\section{QSAR model for antibacterial activity against $S$. aureus}

$$
\begin{aligned}
& \mathrm{pMIC}_{\mathrm{sa}}=-0.128 \mu+2.015 \\
& \mathrm{n}=20 \quad \mathrm{r}=-0.916 \quad \mathrm{r}^{2}=0.839 \mathrm{q}^{2}=0.778 \quad \mathrm{~s}=0.095 \quad \mathrm{~F}=93.95
\end{aligned}
$$

Here and thereafter, $\mathrm{n}$ - number of data points, $\mathrm{r}$ - multiple correlation coefficient, $\mathrm{q}^{2}$ - cross validated $\mathrm{r}^{2}$ obtained by leave one out (LOO) technique, $\mathrm{s}$ - standard error of the estimate and $\mathrm{F}$ Fischer statistics.

The negative coefficient of $\mu$ in the Eq. 1 indicates that there is a negative correlation between the antibacterial activity of substituted hydrazides and $\mu$. This is evidenced by the antibacterial activity data of substituted hydrazides (Table 2) and their $\mu$ values (Table 4). Compound 6 and 16 with minimum $\mu$ values of 3.16 and 2.87 respectively have maximum antibacterial activity against $S$. aureus (Compound $\mathbf{6}, \mathrm{pMIC}_{\mathrm{sa}}=1.60$; compound $16, \mathrm{pMIC}_{\mathrm{sa}}=$ 1.67). Similarly the compound 13 and 14 having maximum $\mu$ values have minimum antibacterial activity. (Compound 13, $\mu=8.29, \mathrm{pMIC}_{\mathrm{sa}}=0.82$; compound 14, $\mu=8.68, \mathrm{pMIC}_{\mathrm{sa}}=0.78$ ). 
Table 4. Values of selected descriptors used in the regression analysis

\begin{tabular}{ccccccccccc}
\hline Comp. & $\log \mathrm{P}$ & $\mathrm{MR}$ & ${ }^{0} \chi$ & ${ }^{1} \chi$ & $\mathrm{R}$ & $\mathrm{B}$ & $\mathrm{W}$ & $\mathrm{Te}$ & LUMO & $\mu$ \\
\hline $\mathbf{1}$ & 0.08 & 43.82 & 8.27 & 5.24 & 5.24 & 2.05 & 160.00 & -1960.67 & -0.15 & 4.77 \\
$\mathbf{2}$ & 1.66 & 46.75 & 8.27 & 5.25 & 5.25 & 2.17 & 152.00 & -2079.08 & -0.52 & 4.20 \\
$\mathbf{3}$ & 0.82 & 46.45 & 9.84 & 6.15 & 6.15 & 2.11 & 262.00 & -2570.35 & -1.64 & 3.31 \\
$\mathbf{4}$ & 0.82 & 46.45 & 9.84 & 6.15 & 6.15 & 2.12 & 250.00 & -2570.36 & -1.50 & 4.47 \\
$\mathbf{5}$ & 1.33 & 44.16 & 8.27 & 5.24 & 5.24 & 2.05 & 160.00 & -1895.46 & -0.31 & 4.58 \\
$\mathbf{6}$ & 1.39 & 43.93 & 8.27 & 5.24 & 5.24 & 2.05 & 160.00 & -2099.67 & -0.63 & 3.16 \\
$\mathbf{7}$ & 0.77 & 53.77 & 12.29 & 7.45 & 7.45 & 2.32 & 427.00 & -3400.91 & -2.07 & 5.26 \\
$\mathbf{8}$ & 0.36 & 52.05 & 10.55 & 6.72 & 6.72 & 2.23 & 307.00 & -2691.17 & -0.28 & 3.34 \\
$\mathbf{9}$ & 0.61 & 45.59 & 8.97 & 5.77 & 5.77 & 2.05 & 210.00 & -2215.47 & -0.27 & 4.24 \\
$\mathbf{1 0}$ & 1.34 & 51.25 & 10.72 & 6.56 & 6.56 & 2.28 & 298.00 & -2930.33 & -1.74 & 5.48 \\
$\mathbf{1 1}$ & 3.69 & 79.01 & 14.37 & 9.69 & 9.69 & 1.47 & 995.00 & -3525.78 & -0.49 & 3.91 \\
$\mathbf{1 2}$ & 3.96 & 81.83 & 14.37 & 9.70 & 9.70 & 1.50 & 969.00 & -3505.17 & -0.27 & 3.50 \\
$\mathbf{1 3}$ & 3.64 & 86.34 & 16.82 & 10.99 & 10.99 & 1.53 & 1410.00 & -4356.52 & -1.36 & 8.29 \\
$\mathbf{1 4}$ & 3.13 & 81.53 & 15.95 & 10.60 & 10.60 & 1.50 & 1272.00 & -3996.50 & -1.17 & 8.68 \\
$\mathbf{1 5}$ & 2.89 & 64.94 & 12.09 & 8.25 & 8.25 & 1.48 & 613.00 & -3085.47 & -0.73 & 2.84 \\
$\mathbf{1 6}$ & 3.17 & 67.76 & 12.09 & 8.27 & 8.27 & 1.53 & 593.00 & -3064.92 & -0.33 & 2.87 \\
$\mathbf{1 7}$ & 2.85 & 72.27 & 14.54 & 9.58 & 9.58 & 1.58 & 910.00 & -3916.25 & -1.47 & 4.81 \\
$\mathbf{1 8}$ & 2.33 & 67.46 & 13.66 & 9.16 & 9.16 & 1.50 & 815.00 & -3556.28 & -1.23 & 7.07 \\
$\mathbf{1 9}$ & 1.59 & 64.84 & 12.09 & 8.25 & 8.25 & 1.48 & 613.00 & -2946.52 & -0.33 & 3.94 \\
$\mathbf{2 0}$ & 2.33 & 67.46 & 13.66 & 9.16 & 9.16 & 1.51 & 845.00 & -3556.28 & -1.43 & 5.31 \\
\hline & & & & & & & & & &
\end{tabular}

Table 5. Correlation matrix for pMICsa with molecular descriptors

\begin{tabular}{lrrrrrrrrrrr}
\hline & pMICsa & Log P & MR & $\kappa_{1}$ & \multicolumn{1}{c}{$\kappa_{2}$} & $\kappa \alpha_{1}$ & $\kappa \alpha_{2}$ & W & Te & LUMO $\mu$ \\
\hline pMICsa & 1.000 & & & & & & & & & & \\
Log P & -0.185 & 1.000 & & & & & & & & & \\
MR & -0.401 & 0.905 & 1.000 & & & & & & & & \\
$\kappa_{1}$ & -0.532 & 0.783 & 0.953 & 1.000 & & & & & & & \\
$\kappa_{2}$ & -0.476 & 0.829 & 0.980 & 0.986 & 1.000 & & & & & & \\
$\kappa \alpha_{1}$ & -0.490 & 0.824 & 0.971 & 0.995 & 0.988 & 1.000 & & & & & \\
$\kappa \alpha_{2}$ & -0.408 & 0.878 & 0.994 & 0.966 & 0.991 & 0.981 & 1.000 & & & & \\
W & -0.558 & 0.844 & 0.975 & 0.974 & 0.984 & 0.977 & 0.976 & 1.000 & & & \\
Te & 0.503 & -0.736 & -0.906 & -0.985 & -0.950 & -0.976 & -0.924 & -0.934 & 1.000 & & \\
LUMO & 0.351 & 0.017 & -0.081 & -0.332 & -0.196 & -0.275 & -0.110 & -0.200 & 0.459 & 1.000 & \\
$\mu$ & -0.916 & 0.235 & 0.429 & 0.565 & 0.502 & 0.522 & 0.433 & 0.583 & -0.565 & -0.450 & 1.000 \\
\hline
\end{tabular}

The importance of dipole moment in modulating antibacterial activity of substituted hydrazides against $S$. aureus may be due to the presence of carbonyl group $\left(\mathrm{C}^{+}-\mathrm{O}^{-}\right)$where 
permanent polarization is seen due to electronegativity difference between the atoms. This permanent polarization may results in a dipole-dipole interaction with antibacterial target. ${ }^{38}$

Squared correlation coefficient $\left(\mathrm{r}^{2}\right)$ of 0.839 in Eq. 1 explains $83.9 \%$ variance in antibacterial activity against $S$. aureus. Eq. 1 also indicated statistical significance of $>99.9 \%$ with $F$ value of 93.95. Similarly the cross validation of obtained Eq. 1 was subsequently checked by employing "leave one out" (LOO) method. ${ }^{39}$ The $\mathrm{q}^{2}$ value of Eq. $1\left(\mathrm{q}^{2}=0.778 ; \mathrm{q}^{2}>0.5\right)$ qualify it to be a valid model according to recommendations of Golbraikh and Trophsa. ${ }^{40}$

In order to confirm our results we have predicted the antibacterial activity of substituted hydrazides against $S$. aureus using Eq. 1. The comparison of observed and predicted values (Table 7) demonstrated that they are close to each other evidenced by the low residual activity values. Further it is supported by the plot of $\mathrm{pMIC}_{\mathrm{sa}}$ observed vs pMIC $\mathrm{sa}$ predicted (Fig. 2). To determine the existence of systemic error in the model development we have plotted $\mathrm{pMIC}_{\mathrm{sa}}$ observed against $\mathrm{pMIC}_{\mathrm{sa}}$ residual values (Fig. 3). The propagation of residuals on both sides of zero indicated that there is no systemic error in the development of QSAR model. ${ }^{41}$ The QSAR models elicited in Eq. 2 - Eq. 4 are developed to predict the antimicrobial activity of substituted hydrazide derivatives against $B$. subtilis, E. coli and A. niger.

Table 6. Correlation of different molecular descriptors with antimicrobial activity of substituted benzoic acid benzylidene/furan-2-yl-methylene hydrazides

\begin{tabular}{cccccc}
\hline & pMICsa & pMICbs & pMICec & pMICca & pMICan \\
\hline LOGP & -0.185 & 0.324 & 0.157 & -0.144 & -0.045 \\
MR & -0.401 & 0.234 & -0.014 & -0.270 & -0.005 \\
${ }^{0} \chi$ & -0.513 & 0.110 & -0.171 & -0.258 & 0.185 \\
${ }^{0} \chi^{\mathrm{v}}$ & -0.350 & 0.271 & 0.028 & -0.280 & -0.003 \\
${ }^{1} \chi$ & -0.455 & 0.172 & -0.101 & -0.277 & 0.094 \\
${ }^{1} \chi^{\mathrm{v}}$ & -0.318 & 0.298 & 0.059 & -0.279 & -0.037 \\
${ }^{2} \chi$ & -0.482 & 0.138 & -0.150 & -0.249 & 0.182 \\
${ }^{2} \chi^{\mathrm{v}}$ & -0.291 & 0.312 & 0.077 & -0.251 & -0.007 \\
$\kappa_{1}$ & -0.532 & 0.091 & -0.187 & -0.257 & 0.195 \\
$\kappa_{2}$ & -0.476 & 0.150 & -0.103 & -0.285 & 0.061 \\
$\mathrm{~K}_{1}$ & -0.490 & 0.139 & -0.139 & -0.271 & 0.162 \\
$\mathrm{~K}_{2}$ & -0.408 & 0.220 & -0.031 & -0.302 & 0.008 \\
$\mathrm{R}$ & -0.455 & 0.172 & -0.101 & -0.277 & 0.094 \\
$\mathrm{~B}$ & 0.151 & -0.332 & -0.166 & 0.231 & 0.257 \\
$\mathrm{~W}$ & -0.558 & 0.042 & -0.193 & -0.239 & 0.089 \\
$\mathrm{Te}$ & 0.503 & -0.085 & 0.216 & 0.275 & -0.315 \\
$\mathrm{LUMO}$ & 0.351 & 0.304 & 0.447 & 0.000 & -0.863 \\
$\mu$ & -0.916 & -0.684 & -0.814 & 0.032 & 0.342 \\
\hline
\end{tabular}


Table 7. Observed and predicted antimicrobial activities of substituted benzoic acid benzylidene/furan-2-yl-methylene hydrazides using Eq. 1 - Eq. 4

\begin{tabular}{ccccccccccccc}
\hline \multirow{2}{*}{ Comp. } & \multicolumn{3}{c}{ pMICsa } & \multicolumn{3}{c}{ pMICbs } & \multicolumn{3}{c}{ pMICec } & \multicolumn{3}{c}{ pMICan } \\
\cline { 2 - 12 } & Obs. & Pre. & Res. & Obs. & Pre. & Res. & Obs. & Pre. & Res. & Obs. & Pre. & Res. \\
\hline $\mathbf{1}$ & 1.40 & 1.40 & 0.00 & 1.38 & 1.20 & 0.18 & 1.38 & 1.29 & 0.09 & 1.38 & 1.37 & 0.01 \\
$\mathbf{2}$ & 1.54 & 1.47 & 0.07 & 1.54 & 1.42 & 0.12 & 1.54 & 1.42 & 0.12 & 1.41 & 1.40 & 0.01 \\
$\mathbf{3}$ & 1.46 & 1.59 & -0.13 & 1.46 & 1.94 & -0.48 & 1.46 & 1.59 & -0.13 & 1.46 & 1.50 & -0.04 \\
$\mathbf{4}$ & 1.46 & 1.44 & 0.02 & 1.46 & 1.51 & -0.05 & 1.46 & 1.37 & 0.09 & 1.46 & 1.48 & -0.02 \\
$\mathbf{5}$ & 1.38 & 1.43 & -0.05 & 1.38 & 1.27 & 0.11 & 1.38 & 1.33 & 0.05 & 1.40 & 1.39 & 0.01 \\
$\mathbf{6}$ & 1.60 & 1.61 & -0.01 & 1.44 & 1.80 & -0.36 & 1.44 & 1.59 & -0.15 & 1.44 & 1.41 & 0.03 \\
$\mathbf{7}$ & 1.26 & 1.34 & -0.08 & 1.56 & 1.49 & 0.07 & 1.26 & 1.28 & -0.02 & 1.54 & 1.53 & 0.01 \\
$\mathbf{8}$ & 1.50 & 1.58 & -0.08 & 2.06 & 2.05 & 0.01 & 1.50 & 1.63 & -0.13 & 1.36 & 1.38 & -0.02 \\
$\mathbf{9}$ & 1.42 & 1.47 & -0.05 & 1.12 & 1.51 & -0.39 & 1.40 & 1.40 & 0.00 & 1.42 & 1.38 & 0.04 \\
$\mathbf{1 0}$ & 1.48 & 1.31 & 0.17 & 1.84 & 1.22 & 0.62 & 1.24 & 1.22 & 0.02 & 1.54 & 1.50 & 0.04 \\
$\mathbf{1 1}$ & 1.50 & 1.51 & -0.01 & 2.57 & 2.46 & 0.11 & 1.97 & 1.76 & 0.21 & 1.36 & 1.40 & -0.04 \\
$\mathbf{1 2}$ & 1.57 & 1.56 & 0.01 & 2.63 & 2.62 & 0.01 & 2.03 & 1.87 & 0.16 & 1.43 & 1.38 & 0.05 \\
$\mathbf{1 3}$ & 0.82 & 0.95 & -0.13 & 0.82 & 1.11 & -0.29 & 0.82 & 1.00 & -0.18 & 1.52 & 1.47 & 0.05 \\
$\mathbf{1 4}$ & 0.78 & 0.90 & -0.12 & 0.70 & 0.89 & -0.19 & 0.70 & 0.88 & -0.18 & 1.45 & 1.46 & -0.01 \\
$\mathbf{1 5}$ & 1.60 & 1.65 & -0.05 & 2.50 & 2.56 & -0.06 & 1.60 & 1.84 & -0.24 & 1.40 & 1.42 & -0.02 \\
$\mathbf{1 6}$ & 1.67 & 1.65 & 0.02 & 2.57 & 2.55 & 0.02 & 1.80 & 1.86 & -0.06 & 1.37 & 1.39 & -0.02 \\
$\mathbf{1 7}$ & 1.50 & 1.40 & 0.10 & 2.20 & 2.11 & 0.09 & 1.50 & 1.53 & -0.03 & 1.46 & 1.48 & -0.02 \\
$\mathbf{1 8}$ & 1.26 & 1.10 & 0.16 & 1.26 & 1.18 & 0.08 & 1.26 & 1.06 & 0.20 & 1.43 & 1.46 & -0.03 \\
$\mathbf{1 9}$ & 1.50 & 1.51 & -0.01 & 2.47 & 2.15 & 0.32 & 1.60 & 1.63 & -0.03 & 1.36 & 1.39 & -0.03 \\
$\mathbf{2 0}$ & 1.50 & 1.33 & 0.17 & 1.90 & 1.83 & 0.07 & 1.62 & 1.40 & 0.22 & 1.51 & 1.48 & 0.03 \\
\hline & & & & & & & & & & &
\end{tabular}




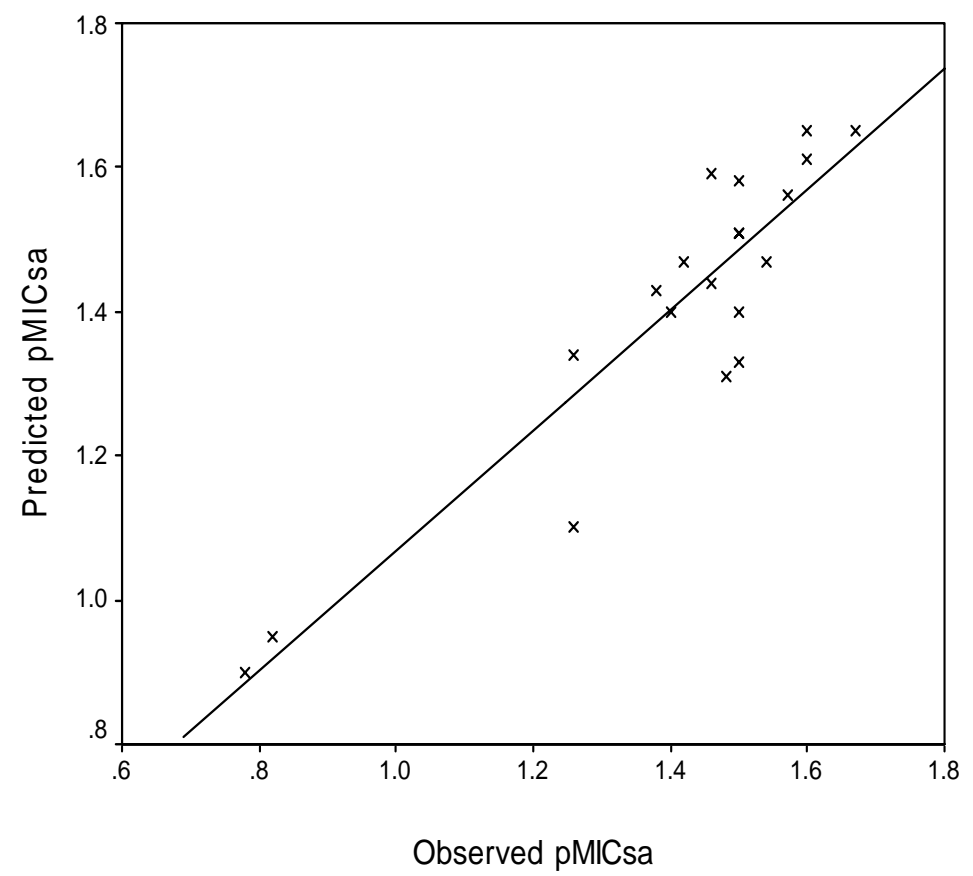

Figure 2. Plot of predicted pMICsa activity values against the experimental pMICsa values for the linear regression developed model by Eq. 1.

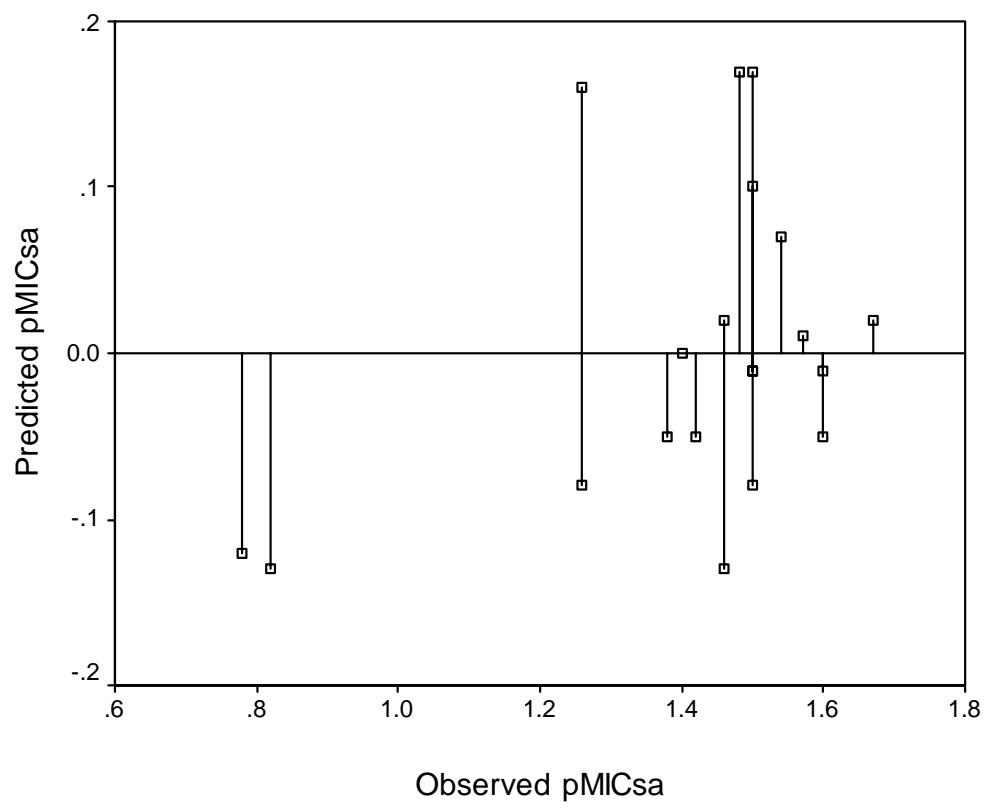

Figure 3. Plot of residual pMICsa values against the experimental pMICsa values. 
QSAR model for antibacterial activity against $B$. subtilis

$$
\begin{aligned}
& \mathrm{pMIC}_{\mathrm{bs}}=0.211 \mathrm{R}-0.370 \mu+1.863 \\
& \mathrm{n}=20 \quad \mathrm{r}=0.905 \quad \mathrm{r}^{2}=0.819 \quad \mathrm{q}^{2}=0.753 \quad \mathrm{~s}=0.268 \quad \mathrm{~F}=34.48
\end{aligned}
$$

QSAR model for antibacterial activity against $E$. coli

$$
\begin{aligned}
& \mathrm{pMIC}_{\mathrm{ec}}=0.009 \mathrm{MR}-0.189 \mu+1.803 \\
& \mathrm{n}=20 \quad \mathrm{r}=0.894 \quad \mathrm{r}^{2}=0.779 \quad \mathrm{q}^{2}=0.689 \quad \mathrm{~s}=0.149 \quad \mathrm{~F}=34.16
\end{aligned}
$$

\section{QSAR model for antifungal activity against $A$. niger}

$$
\begin{array}{lccccc}
\mathrm{pMIC}_{\mathrm{an}}= & -0.082 \mathrm{LUMO}+1.361 \\
\mathrm{n}=20 & \mathrm{r}=0.863 & \mathrm{r}^{2}=0.744 & \mathrm{q}^{2}=0.719 \quad \mathrm{~s}=0.030 \quad \mathrm{~F}=52.65
\end{array}
$$

Eq. 2 describes the importance of randic topological index (R) and dipole moment $(\mu)$ in demonstrating antibacterial activity of substituted hydrazide derivatives against $B$. subtilis. As in case of $S$. aureus the negative correlation has been observed with dipole moment where as randic topological index gave positive contribution. It is important to note the addition of randic topological index to the dipole moment significantly improved the correlation from $\mathrm{r}=0.681$ (Table 6) to 0.905 (Eq. 2) on MLR analysis. Further, it is important to note that the autocorrelation between $\mathrm{R}$ and $\mu$ are also low $(\mathrm{r}=0.500)$, which justifies their combination.

The model depicted in Eq. 3 describes the statistically significant relationship between molar refractivity (MR) and dipole moment $(\mu)$ in describing the antibacterial activity of substituted hydrazide derivatives against E. coli. In this case also the positive and negative relationship was observed between MR and $\mu$ respectively with their antibacterial activity. The positive contribution of molar refractivity towards the activity is possible due to steric interaction in polar spaces. All the synthesized compounds bearing para and ortho electron withdrawing substituents have been found to be more active than the compounds bearing electron withdrawing group at meta position indicated that meta substitution decreases the activity against E. coli where as ortho or para substitution increases the antibacterial activity of substituted hydrazide derivatives against E. coli. This is in contrary to the results observed by A. Kumar et al. ${ }^{42}$

The model described in Eq. 4 indicated the importance of electronic parameter LUMO $(\mathrm{r}=$ 0.823 , Table 6 ) in demonstrating antifungal activity of substituted hydrazide derivatives against A. niger. It is important to note that electronic parameter dipole moment $(\mu)$ which was effective in describing antifungal activity (Eq. 1-3) of substituted hydrazide derivatives was found ineffective in describing the antifungal activity $(\mathrm{r}=0.342$, Table 6$)$. This supports the fact described in the structure activity relationship that different structural requirements are necessary for a substituted hydrazide derivative to be active against fungal strains.

The electronic parameter LUMO, which denote the energy of lowest unoccupied molecular orbital directly relates to the electron affinity and characterizes the sensibility of the molecule towards an attack by necleophile ${ }^{43}$. The contribution of LUMO in describing antifungal activity may be attributed to the interaction of substituted hydrazide derivatives with nucleophilic amino acid residue like cysteine of fungi. ${ }^{44}$

Similar to Eq. 1 the high $\mathrm{q}^{2}$ values $\left(\mathrm{q}^{2}>0.5\right)$ obtained by leave one out technique and the observance of low residual values (Table 7) indicated the validity and predictability of Eqs. 2 - 
4. Further their predictability was supported by the plot of predicted pMIC against observed pMIC (Fig. 4 - Fig. 6).

It is important to note that Eq. 1 - Eq. 4 are derived using the entire data set and no outliers were found during model development. Even though the sample size and the 'Rule of Thumb' allowed us to go for development of tetra-parametric model in multiple linear regression analysis, the high interrelationship among the parameters restricted us for mono-parametric model in case of S. aureus and A. niger. The 'rule of thumb' gives information about the number of parameters to be selected for regression analysis in QSAR based on the number of compounds. ${ }^{22}$ According to this rule for QSAR model development one should select one parameter for a five-compound data set.

The multi-colinearity occurs when two independent variables are correlated with each other. One should note that the change in signs of the coefficients, a change in the values of previous coefficient, change of significant variable into insignificant one or an increase in standard error of the estimate on addition of an additional parameter to the model are indications of high interrelationship among descriptors. $^{22}$

Generally for QSAR studies, the biological activities of compounds should span 2-3 orders of magnitude. But in the present study the range of antimicrobial activities of the synthesized compounds is within one order of magnitude. But it is important to note that the predictability of the QSAR models developed in the present study is high evidenced by the low residual values (Table 7). This is in accordance with results suggested by the Bajaj et al. ${ }^{45}$, who stated that the reliability of the QSAR model lies in its predictive ability even though the activity datas are in the narrow range. Further, recent literature reveals that the QSAR have been applied to describe the relationship between narrow range of biological activity and physicochemical properties of the molecules. ${ }^{42,46-47}$ When biological activity data lies in the narrow range, the presence of minimum standard deviation of the biological activity justifies its use in QSAR studies. ${ }^{19,24}$ The minimum standard deviation (Table 2) observed in the antimicrobial activity data justifies its use in QSAR studies. 


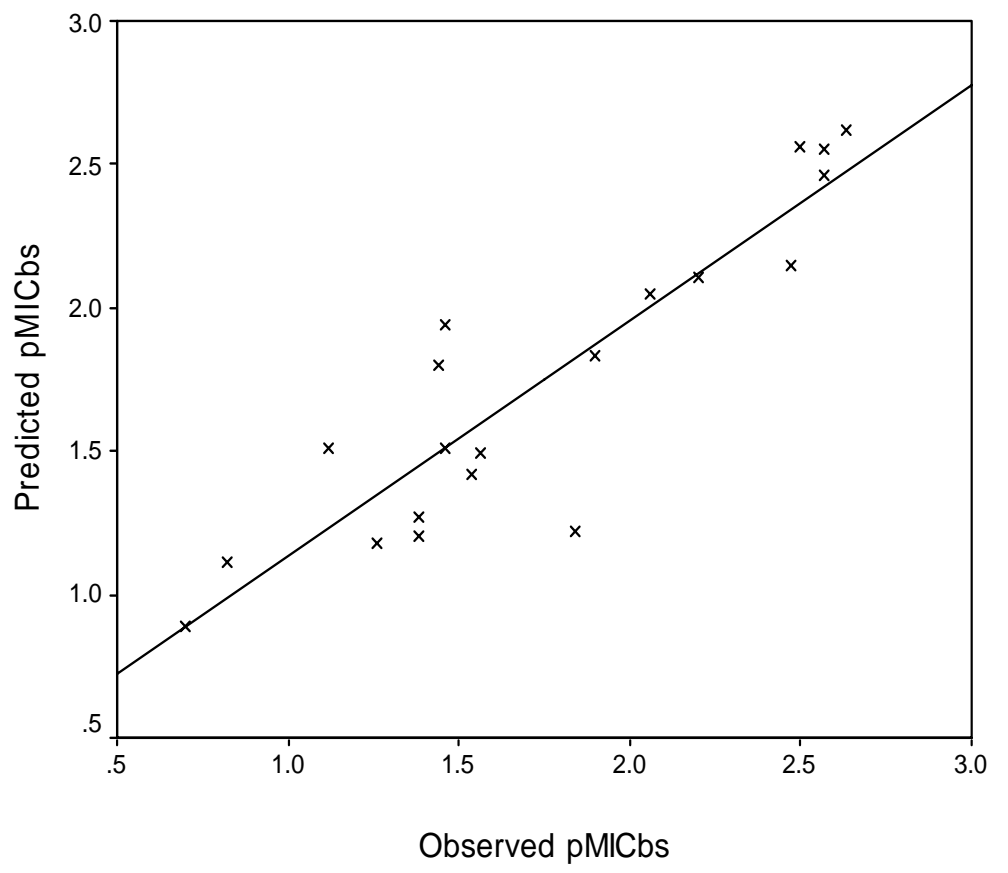

Figure 4. Plot of predicted pMICbs activity values against the experimental pMICbs values for the linear regression developed model by Eq. 2 .

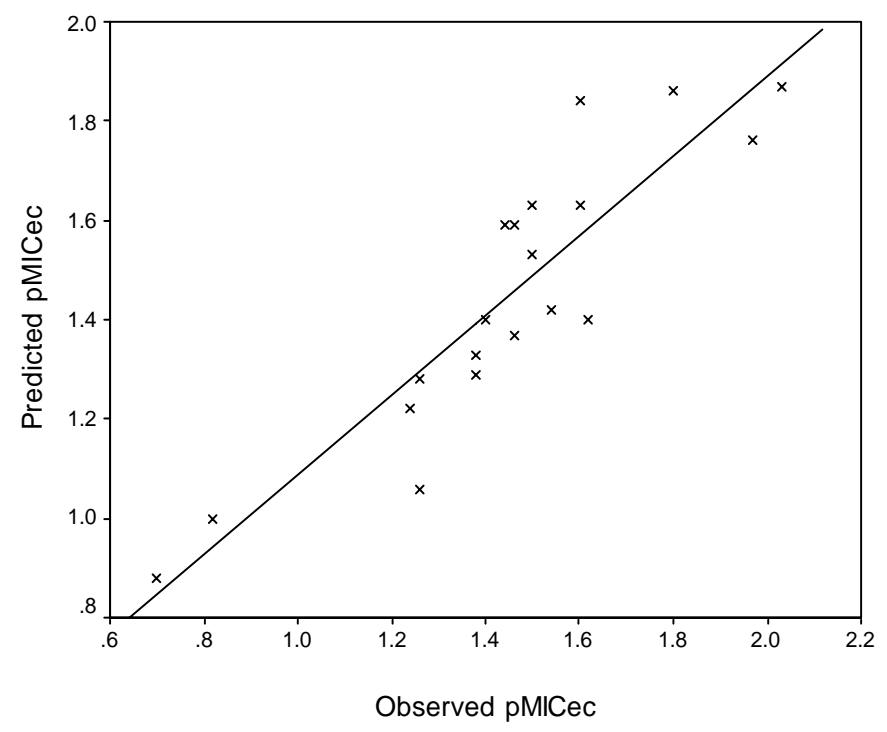

Figure 5. Plot of predicted pMICec activity values against the experimental pMICec values for the linear regression developed model by Eq. 3 . 


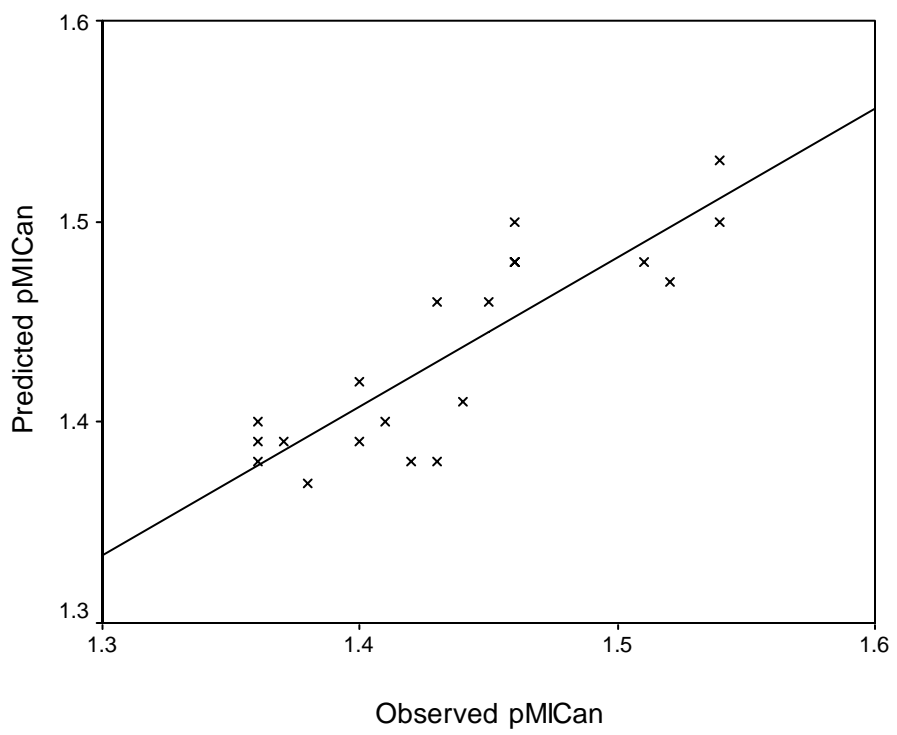

Figure 6. Plot of predicted pMICan activity values against the experimental pMICan values for the linear regression developed model by Eq. 4.

\section{Conclusion}

In conclusion, a series of substituted hydrazide derivatives have been synthesized and their in vitro antimicrobial activity was evaluated against four representative microorganisms. The results of antimicrobial study indicated that the presence of halo group in aromatic ring improved antibacterial activity, whereas the presence of nitro group improved antifungal activity of substituted hydrazides. To understand the relationship between physicochemical parameters and antimicrobial activity of substituted hydrazide derivatives, QSAR investigation were performed and the QSAR results indicated the predominance of electronic parameters, dipole moment, $\mu$ and the energy of lowest unoccupied molecular orbital, LUMO in describing the antimicrobial activity of synthesized compounds.

\section{Experimental Section}

General Procedures. Starting materials were obtained from commercial sources and were used without further purification. Solvents were dried by standard procedures. Reaction progress was observed by thin layer chromatography making use of commercial silica gel plates (Merck), Silica gel $\mathrm{F}_{254}$ on aluminum sheets. Melting points were determined in open capillary tubes on a Sonar melting point apparatus and are uncorrected. ${ }^{1} \mathrm{H}$ nuclear magnetic resonance $\left({ }^{1} \mathrm{H} \mathrm{NMR}\right)$ spectra were determined by Bruker Avance II 400 NMR spectrometer in appropriate deuterated solvents and are expressed in parts per million $(\delta, \mathrm{ppm})$ downfield from tetramethylsilane 
(internal standard) NMR data are given as multiplicity (s, singlet; d, doublet; t, triplet; m, multiplet) and number of protons. Infrared (IR) spectra were recorded on a Shimadzu FTIR spectrometer.

\section{General procedure for the synthesis of substituted benzoic acid hydrazides (1-10)}

Thionyl chloride $32.8 \mathrm{~g}(0.3 \mathrm{~mol})$ was added to substituted benzoic acid $(0.25 \mathrm{~mol})$ in a round bottom flask. After addition, the mixture was refluxed for $2 \mathrm{~h}$. The excess of thionyl chloride was removed by distillation. To the solution of $0.05 \mathrm{~mol}$ of substituted acid chloride in methanol added $0.1 \mathrm{~mol}$ of hydrazine hydrate. The mixture was refluxed for $30 \mathrm{~min}$. Then the reaction mixture was cooled and the resultant precipitate was collected, washed with distilled water and recrystallized from ethanol.

General procedure for the synthesis of substituted benzoic acid benzylidene/furan-2-ylmethylene hydrazides (11-20)

A solution of $0.005 \mathrm{~mol}$ of substituted aldehyde [benzaldehyde (11-14) / Furan-2-aldehyde (1520)] in ethanol was added to a solution of corresponding $0.05 \mathrm{~mol}$ of substituted benzoic acid hydrazides (1-10) in $50 \mathrm{~mL}$ ethanol. The mixture was refluxed on a water bath for $3 \mathrm{~h}$. Then the reaction mixture was allowed to cool at room temperature and the precipitate obtained was filtered, dried and recrystallized from ethanol.

Compound 1. $\mathrm{Mp}\left({ }^{0} \mathrm{C}\right) 40-43$; Yield $-74 \%$; ${ }^{1} \mathrm{H}$ NMR $\left(\mathrm{CDCl}_{3}\right): \delta 6.55-6.58\left(\mathrm{~d}, 2 \mathrm{H}, \mathrm{CH}\right.$ of $\mathrm{C}_{3}$ and $\mathrm{C}_{5}$ of $\left.\mathrm{Ar}-\mathrm{H}\right), 7.63-7.65$ (d, 2H, CH of $\mathrm{C}_{2}$ and $\mathrm{C}_{6}$ of Ar-H); IR (KBr pellets): $\mathrm{cm}^{-1} 1640$ $(\mathrm{C}=\mathrm{O}), 807(\mathrm{C}-\mathrm{H}), 3344(\mathrm{~N}-\mathrm{H})$.

Compound 2. $\mathrm{Mp}\left({ }^{0} \mathrm{C}\right) 145$ - 148; Yield - $46 \% ;{ }^{1} \mathrm{H}$ NMR $\left(\mathrm{CDCl}_{3}\right): \delta 7.30-7.33(\mathrm{~d}, 2 \mathrm{H}, \mathrm{CH}$ of $\mathrm{C}_{4}$ and $\mathrm{C}_{5}$ of $\left.\mathrm{Ar}-\mathrm{H}\right), 7.52-7.62\left(\mathrm{~m}, 1 \mathrm{H}, \mathrm{CH}\right.$ of $\mathrm{C}_{3}$ of $\left.\mathrm{Ar}-\mathrm{H}\right), 7.69-7.72\left(\mathrm{~d}, 1 \mathrm{H}, \mathrm{CH}\right.$ of $\mathrm{C}_{6}$ of Ar$\mathrm{H})$; IR (KBr pellets): $\mathrm{cm}^{-1} 1653(\mathrm{C}=\mathrm{O}), 743(\mathrm{C}-\mathrm{H}), 3534(\mathrm{~N}-\mathrm{H})$.

Compound 3. $\mathrm{Mp}\left({ }^{0} \mathrm{C}\right)$ 90-93; Yield $-80 \% ;{ }^{1} \mathrm{H}$ NMR $\left(\mathrm{CDCl}_{3}\right): \delta 8.09-8.13(\mathrm{dd}, 2 \mathrm{H}, \mathrm{CH}$ adj. to $\mathrm{C}=\mathrm{O}$ of $\mathrm{Ar}-\mathrm{H}), 8.17-8.22\left(\mathrm{dd}, 2 \mathrm{H}, \mathrm{CH}\right.$ adj. to $\mathrm{NO}_{2}$ of $\left.\mathrm{Ar}-\mathrm{H}\right) ; \quad \mathrm{IR}$ (KBr pellets): $\mathrm{cm}^{-1}$ 1525 $\left(\mathrm{NO}_{2}\right), 1684(\mathrm{C}=\mathrm{O}), 823(\mathrm{C}-\mathrm{H}), 3447(\mathrm{~N}-\mathrm{H})$.

Compound 4. $\mathrm{Mp}\left({ }^{0} \mathrm{C}\right) 105-108$; Yield $-83 \%$; ${ }^{1} \mathrm{H}$ NMR $\left(\mathrm{CDCl}_{3}\right): \delta 8.57-8.59(\mathrm{~s}, 1 \mathrm{H}, \mathrm{CH}$ between $\mathrm{C}=\mathrm{O}$ and $\mathrm{NO}_{2}$ of $\left.\mathrm{Ar}-\mathrm{H}\right), 8.32-8.33$ (s, $1 \mathrm{H}, \mathrm{CH}$ adj. to $\mathrm{NO}_{2}$ of $\left.\mathrm{Ar}-\mathrm{H}\right) ; 8.24$ (s, $1 \mathrm{H}, \mathrm{CH}$ of $\mathrm{C}_{6}$ of $\left.\mathrm{Ar}-\mathrm{H}\right), 7.66-7.72\left(\mathrm{~m}, 1 \mathrm{H}, \mathrm{CH}\right.$ of $\mathrm{C}_{5}$ of $\left.\mathrm{Ar}-\mathrm{H}\right)$; IR (KBr pellets): $\mathrm{cm}^{-1} 1528\left(\mathrm{NO}_{2}\right)$, 1654( $\mathrm{C}=\mathrm{O}), 721(\mathrm{C}-\mathrm{C}), 1356(\mathrm{~N}-\mathrm{H})$.

Compound 5. $\mathrm{Mp}\left({ }^{0} \mathrm{C}\right) 35-38$; Yield - $73 \% ;{ }^{1} \mathrm{H} \mathrm{NMR}\left(\mathrm{CDCl}_{3}\right): \delta 2.33\left(\mathrm{~s}, 3 \mathrm{H}, \mathrm{CH}_{3}\right), 7.16-7.18$ (d, 2H, $\mathrm{CH}$ of $\mathrm{C}_{3}$ and $\mathrm{C}_{5}$ of $\left.\mathrm{Ar}-\mathrm{H}\right), 7.81-7.83$ (d, 2H, $\mathrm{CH}$ of $\mathrm{C}_{2}$ and $\mathrm{C}_{6} \mathrm{Ar}-\mathrm{H}$ ); IR (KBr pellets): $\mathrm{cm}^{-1} 1663(\mathrm{C}=\mathrm{O}), 809(\mathrm{C}-\mathrm{H}), 3376(\mathrm{~N}-\mathrm{H})$.

Compound 6. $\mathrm{Mp}\left({ }^{0} \mathrm{C}\right) 130-133$; Yield - $55 \%$; ${ }^{1} \mathrm{H}$ NMR $\left(\mathrm{CDCl}_{3}\right): \delta 7.29-7.33(\mathrm{dd}, 2 \mathrm{H}, \mathrm{CH}$ of $\mathrm{C}_{3}$ and $\mathrm{C}_{5}$ of $\left.\mathrm{Ar}-\mathrm{H}\right), 7.75-7.78\left(\mathrm{dd}, 2 \mathrm{H}, \mathrm{CH}\right.$ of $\mathrm{C}_{2}$ and $\left.\mathrm{C}_{6} \mathrm{Ar}-\mathrm{H}\right)$; IR (KBr pellets): $\mathrm{cm}^{-1} 732$ (C$\mathrm{Cl}), 1663(\mathrm{C}=\mathrm{O}), 839(\mathrm{C}-\mathrm{H})$.

Compound 19. $\mathrm{Mp}\left({ }^{0} \mathrm{C}\right)$ 100-103; Yield $-62 \%$; ${ }^{1} \mathrm{H}$ NMR $\left(\mathrm{CDCl}_{3}\right): \delta 6.50-6.51(\mathrm{~m}, 2 \mathrm{H}, \mathrm{CH}$ of $\mathrm{C}_{3}$ and $\mathrm{C}_{4}$ of Furan), $7.70-7.78\left(\mathrm{~m}, 2 \mathrm{H}, \mathrm{CH}\right.$ of $\mathrm{C}_{2}$ and $\left.\mathrm{C}_{6} \mathrm{Ar}-\mathrm{H}\right), 6.70-6.74\left(\mathrm{~m}, 2 \mathrm{H}, \mathrm{CH}\right.$ of $\mathrm{C}_{3}$ 
and $\left.\mathrm{C}_{5} \mathrm{Ar}-\mathrm{H}\right), 7.36$ (s, 1H, CH of N=CH); IR (KBr pellets): $\mathrm{cm}^{-1} 1653(\mathrm{C}=\mathrm{O}), 796(\mathrm{C}-\mathrm{H}$ of ArH), 1014 (2-Furan).

\section{Evaluation of antimicrobial activity}

The antimicrobial activity was performed against Gram-positive bacteria: Staphylococcus aureus, Bacillus sublitis, Gram-negative bacterium: E.coli and a fungal strain: Aspergillus niger. The minimum inhibitory concentration (MIC) was determined by tube dilution method. Two fold dilutions of test and standard compounds were prepared in double strength nutrient broth - I.P. (bacteria) or Sabouraud dextrose broth I.P. ${ }^{48}$ (fungi). The samples were incubated at $37^{0} \mathrm{C}$ (bacteria) for $24 \mathrm{~h}$ and at $25^{\circ} \mathrm{C}$ (fungi) for $7 \mathrm{~d}$ and the results were recorded. Growth of microorganism was determined visually. The lowest concentration at which there was no visible growth (turbidity) was taken as MIC.

\section{QSAR studies}

The details of molecular descriptors are available in literature and therefore they are not discussed over here. ${ }^{30-36}$ The structures of substituted hydrazide derivatives are first preoptimized with the Molecular Mechanics Force Field $\left(\mathrm{MM}^{+}\right)$procedure included in Hyperchem $6.03,{ }^{49}$ and the resulting geometries are further refined by means of the semiempirical method $\mathrm{PM}_{3}$ (Parametric Method-3). We chose a gradient norm limit of $0.01 \mathrm{kcal} / \mathrm{A}^{\circ}$ for the geometry optimization. The lowest energy structure was used for each molecule to calculate physicochemical properties using TSAR 3.3 software for windows. ${ }^{37}$ Further the regression analysis was performed using the SPSS software package. ${ }^{50}$

\section{Cross-validation}

The models were cross-validated by the 'leave one out' scheme ${ }^{39}$ where a model is built with $\mathrm{N}$ 1 compounds and the $\mathrm{N}^{\text {th }}$ compound is predicted. Each compound is left out of the model derivation and predicted in turn. An indication of the performance of the model is obtained from the cross-validated (or predictive $\mathrm{q}^{2}$ ) method, which is defined as, $\mathrm{q}^{2}=($ SD-PRESS/SD).

Where, SD is the sum of squares deviation for each activity from the mean. PRESS (predictive sum-of-squares) is the sum of the squared difference between the actual and that of the predicted values when the compound is omitted from the fitting process. The model with high $\mathrm{q}^{2}$ value is said to have high predictability.

\section{References}

1. Foroumadi, A.; Shahla, M.; Kiani, Z.; Rahmani, A. Eur. J. Med. Chem. 2003, 38, 851.

2. Khalafi-Nezhad, A.; Rad, M. N. S.; Mohabatkar, H.; Asari, Z.; Hemmateenejad, B. Bioorg. Med. Chem. 2005, 13, 1931. 
3. Ragavendran, J.; Sriram, D.; Patel, S.; Reddy, I.; Bharathwajan, N.; Stables, J.; Yogeeswari, P. Eur. J. Med. Chem. 2007, 42, 146.

4. Ergenc, N.; Gunay, N. S. Eur. J. Med. Chem. 1998, 33, 143.

5. Todeschini, A. R.; Miranda, A. L.; Silva, C. M.; Parrini, S. C.; Barreiro, E. J. Eur. J. Med. Chem. 1998, 33, 189.

6. Gemma, S.; Kukreja, G.; Fattorusso, C.; Persico, M.; Romano, M.; Altarelli, M.; Savini, L.; Campiani, G.; Fattorusso, E.; Basilico, N. Bioorg. Med. Chem. Lett. 2006, 16, 5384.

7. Bijev, A. Lett. Drug. Des. Discov. 2006, 3, 506.

8. Gursoy, E.; Guzeldemirci-Ulusoy, N. Eur. J. Med. Chem. 2007, 42, 320.

9. Masunari, A.; Tavaris, L. C. Bioorg. Med. Chem. 2007, 15, 4229.

10. Loncle, C.; Brunel, J.; Vidal, N.; Dherbomez, M.; Letourneux, Y. Eur. J. Med. Chem. 2004, 39, 1067.

11. Kucukguzel, S. G.; Mazi, A.; Sahin, F.; Ozturk, S.; Stables, J. P. Eur. J. Med. Chem. 2003, 38, 1005.

12. Vicini, P.; Zani, F.; Cozzini, P.; Doytchinova, I. Eur. J. Med. Chem. 2002, 37, 553.

13. Agrafiotis, D. K.; Bandyopadhyay, D.; Wegner, J. K.; Vilijmen, H. V. J. Chem. Inf. Model. 2007, 47, 1279.

14. Narasimhan, B.; Kothwade, U. R.; Pharande, D. S.; Mourya, V. K.; Dhake, A. S. Indian J. Chem. 2003, 42 (B), 2828.

15. Narasimhan, B.; Belsare, D.; Pharnde, P.; Mourya, V.; Dhake, A. Eur. J. Med. Chem. 2004, 39 (10), 827.

16. Narasimhan, B.; Mourya, V. K.; Dhake, A. S. Bioorg. Med. Chem. Lett. 2006, 16, 3023.

17. Narasimhan, B.; Mourya, V. K.; Dhake, A. S.; Khim. Farm. Zh. 2007, 41(3), 16.

18. Rakesh, N.; Vikramjeet, J.; Sucheta, O.; Ruchita, O.; Narasimhan, B. ARKIVOC 2007, (xv), 112.

19. Narasimhan, B.; Vikramjeet, J.; Rakesh, N.; Sucheta, O.; Ruchita, O. Bioorg. Med. Chem. Lett. 2007, 17, 5836.

20. Gangwal, N. A.; Narasimhan, B.; Mourya, V. K.; Dhake, A. S. Indian J. Het. Chem. 2003, 12, 201.

21. Narasimhan, B.; Ansari, A. H.; Singh, N.; Mourya, V. K.; Dhake, A. S. Chem. Pharm. Bull. 2006, 54(8), 1067.

22. Narasimhan, B.; Kumari, M.; Jain, N.; Dhake, A. S.; Sundaravelan, C. Biorg. Med. Chem. Lett. 2006, 16, 4951.

23. Narasimhan, B.; Kumari, M.; Dhake, A. S.; Sundaravelan, C. ARKIVOC 2006, (xiii), 73.

24. Kumar, A.; Narasimhan, B.; Kumar, D. Biorg. Med. Chem. 2007, 15, 4113.

25. Narasimhan, B.; Dhake, A. S.; Mourya, V. K. ARKIVOC, 2007, 1, 189.

26. Ruchita, O.; Sucheta, O.; Vikramjeet, J.; Rakesh, N.; Ahuja, M.; Narasimhan, B. ARKIVOC 2007, (xiv), 172.

27. Shadomy, S.; Espinel, A. mannul of clinical microbiology; American chemical society for microbiology: Washington, DC, 1980, p. 647. 
28. Sortino, M.; Delgado, P.; Jaurez, S.; Quiroga, J.; Abonia, R.; Insuasey, B.; Nogueras, M.; Rodero, L.; Garibotto, F. M.; Enriz, R. D.; Zacchino, S. A.; Bioorg. Med. Chem. Lett. 2007, 15, 484.

29. Sharma, P.; Rane, N.; Gurram, V. K. Bioorg. Med. Chem. 2004, 14, 4185.

30. Hansch, C.; Fujita, T. J. Am. Chem. Soc. 1964, 86, 1616.

31. Hansch, C.; Leo, A.; Unger, S. H.; Kim, K. H.; Nikaitani, D.; Lien, E. J. J. Med. Chem. 1973, 16, 1207.

32. Kier, L. B.; Hall, L. H. In Molecular Connectivity in Chemistry and Drug Research; Academic Press: New York, 1976: pp 129-145.

33. Randic, M. J. Am. Chem. Soc. 1975, 97, 6609.

34. Balaban, A. T. Chem. Phys. Lett. 1982, 89, 399.

35. Wiener, H. J. Am. Chem. Soc. 1947, 69, 17.

36. Randic, M. Croat. Chem. Acta. 1993, 66, 289.

37. TSAR 3.3 for Windows, Oxford Molecular Limited, 2000.

38. Pillai, A. D.; Rani, S.; Rathod, P. D.; Xavier, F. P.; Vasu, K. K.; Padh, H.; Sundarsanam, V. Bioorg. Med. Chem. 2005, 13, 1275.

39. Agrawal, V. K.; Singh, J.; Mishra, K. C.; Khadikar, P. V.; Jaliwala, Y. A. ARKIVOC 2006, (ii), 162 .

40. Gol Braikh, A.; Trophsa, A. J. Mol. Graphic. Modell. 2002, 20, 269.

41. Heravi, J. M.; Kyani, A. J. Chem. Inf. Comput. Sci. 2005, 44, 1328.

42. Kumar, A.; Sharma, P.; Gurram, V. K.; Rane, N. Bioorg. Med. Chem. Lett. 2006, 16, 2484.

43. Vande waterbeend, H.; Carter, B. F.; Grassy, G.; Kubinyi, H.; Matrin, Y. C.; Tute, M. S.; Villet, P. Abany Molecular Research, Technical report. 1998, Vol. 2.

44. Motta, L. F.; Gaudio, A. C.; Yuji, T. Internet Electron. J. Mol. Des. 2006, 5, 555.

45. Bajaj, S.; Sambi, S.S.; Madan, A. K. Croatica Chemica Acta 2005, 78(2), 165.

46. Sharma, P.; Kumar, A.; Sharma, M. Eur. J. Med. Chem. 2006, 41, 823.

47. Hatya, S. A.; Aki-sener, E.; Tekiner-Gulbas, B.; Yildiz, I.; Temiz-Arpaci, O.; Yalcin, I.; Altanlar, N. Eur. J. Med. Chem. 2006, 41, 1398.

48. Pharmacopoeia of India; Ministry of Health Department: Govt. of India: New Delhi, 1996, Vol-II, p A-88.

49. Hyperchem 6.0, Hypercube, Inc., Florida, 1993.

50. SPSS for windows, version 10.05, SPSS Inc., Bangalore, India, 1999. 